\title{
Interior revitalization of Indonesian National Building Gresik with art deco themed Damar Kurung
}

\author{
Dhimastahta Dhanar Gumilang a,1, Sumarno ${ }^{a}, 2^{*}$ Harmilyanti Sulistiyani $b, 3^{*}$ \\ a Desain Interior, Fakultas Seni Rupa dan Desain, Institut Seni Indonesia Surakarta, Indonesia, \\ ${ }^{b}$ School of Humanities, Vrije Universiteit (VU Amsterdam). \\ 1 dhim.dhan@gmail.com; ${ }^{2}$ sumarnoisi.ska05@gmail.com, ${ }^{* 3}$ hrmillistya@isi-ska.ac.id. \\ * Corresponding Author
}

Received 25 October 2021; accepted 8 November 2021; published 13 December 2021

\section{ABSTRACT}

The Interior Revitalization Planning at the Indonesia National Building in Gresik by adapting Art Deco Style with the theme "Damar Kurung" is en effort to conserve a public space which is a performance building. The building so far tends to be underutilized due to various things, one of which is the condition of the building and its interior which is no longer feasible. Revitalization of important buildings is carried out as an effort to maintain the sustainability of architectural buildings as part of the culture of the people. The activities that are accommodated mainly are traditional arts. Revitalization by utilizing the building as a center for cultural activities for the people of Gresik and its surroundings. This design adopts an art deco style with damar kurung as the theme applied in the interior. Research using the Kurtz programming method. The design includes lobby, canteen, office, control room, auditorium, stage, dressing room, and backstage.

\section{KEYWORDS}

Revitalization

Adaptation

Performance Hall

Art Deco

Damar Kurung

This is an openaccess article under the CC-BY-SA

license

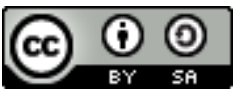

\section{Introduction}

Preservation of culture in each country is important because there are cultural differences in each country and its regions (Prompayuk and Chairattananon 2016). Indonesia itself is a country that has many kinds of cultures, due to the many ethnic groups (Sahertian and Jawas 2021). Various forms and cultural products that are manifested in the arts are the wealth of the nation and the state, as stated in Article 35 of the 1945 Constitution, "The government shall promote the national culture of Indonesia". A culture develops outwardly because culture is a place of exchange and provides the possibility of developing relationships. As one of the largest industrial areas in Indonesia, Gresik Regency is subject to changes, changes in the economy, industrial development, infrastructure development, cultural patterns, as well as social and political arrangements. With changes that are quite rapid and modern, there is a negative impact that is quite felt on the cultural side. Many cultural heritages have begun to be abandoned and forgotten, and one of them is material cultural heritage, such as cultural heritage buildings. In the center of the city, many buildings from the Dutch era or after are old and abandoned without any maintenance. However, some can be saved by turning it into a house for their former descendants or turning it into a hotel, shop, and so on.

One of the abandoned buildings in Gresik is the Indonesian National Building (GNI). The building, which was founded on August 17, 1960, is one of the cultural heritage buildings in Gresik. At first, the building functioned as a show building. But over time the initial function of the building slowly turned into a hall which is usually used for formal meetings, school farewells, and wedding receptions. In 2014, the Gresik Regency Government planned to revitalize the GNI so that it could return to function and not be neglected. According to Noto Utomo Indonesian Democratic Party of Struggle Faction (FPDIP) Regional People's Representative Assembly (DPRD) Gresik, based on a study conducted by the Gresik Regency Government's Culture, Youth and Sports Office, that GNI is not cultural heritage. Because after the establishment of the GNI was prosecuted, it started from the forerunner of the desire of some 
figures in Gresik Regency who wanted to have a representative performance building and finally these figures raised funds for the construction of GNI. However, this statement caused rejection in some circles. According to those who refuse, the revitalization of GNI will change the main function of the previous GNI which was the only representative performance building in Gresik. In 2016, a representative from the Gresik Tourism and Culture Office, Pak Khairil, represented the trial in Jakarta to determine whether GNI was a cultural heritage building or not. With the trial, it was decided GNI as a Cultural Conservation building based on Law no. 11 of 2010 concerning Cultural Conservation. The meeting also resulted in a decision that GNI would not only be revitalized but would be revitalized by means of adaptation so that the main function of the building was maintained and the building could still be renovated.

Adaptation is an effort to develop Cultural Conservation for activities that are more in line with current needs by making limited changes that will not result in a decline in its importance or damage to parts that have important values (Shahi et al. 2020). As intended, it can be concluded that adaptation still maintains the values attached to the cultural heritage, adds facilities as needed, changes the arrangement of space in a limited way, and/or maintains the original architectural style of construction and the aesthetic harmony of the surrounding environment (Shahi et al. 2020). Based on the description above, the plan is an effort to restore the main function of the building that has long changed and also make it a representative building in Gresik. Several room facilities will also be added and improved following the requirements to build a performance hall, such as a lobby, canteen, a more appropriate management office, dressing room, talent transit room, stage, auditorium, and service area. In addition, the plan is also to strengthen the Art Deco style, which is the style of the original architecture and will also apply the theme "Damar Kurung" which is one of the original cultural heritage from Gresik that still exist today. The theme will be applied to the interior, both in the building elements, forming elements, and filling elements, giving rise to Gresik's local wisdom.

The planning for the revitalization of the interior adaptation of GNI Gresik has several facilities and some of these facilities will be added to it, including the lobby area, stage, makeup room, backstage, control room, office, and canteen. In addition, this plan also applies an art deco style to the interior, which is a flow of art style that characterizes luxury and freedom. Art deco appears simpler and more geometric without losing the classic impression. This was adapted to the demands of industrialization at the time. The theme raised in this plan is damar kurung. Damar Kurung is a paper lantern craft with a framework made of cut bamboo blades facing each other to form a square with oil paper attached on all four sides, the blanks of which are painted with various funny pictures that tell of major activities around the community (Wahyu 2013); (Christianna 2018). Gresik, such as the milkfish market festival, takbiran activities to welcome Eid al-Fitr, etc. In its linguistic sense, 'damar' means a lamp or candle, and 'kurung' means a lid, so Damar Kurung means, a lamp that is closed or locked up. According to the word Damar Kurung has the meaning of mendamari which means to illuminate.

\section{Method}

The research was conducted using a functional approach, an ergonomic approach and an aesthetic approach. The design programming method at GNI Gresik uses the Kurtz programming method. Orientation, is the stage of reviewing the philosophy, activities and goals to be achieved by the client based on consultation with the client. Base program, it is the stage of assessing client needs, reviewing supporting alternatives and the initial plan of the program consisting of building organization, activity area, relationship and space size. Interative programming, is the stage of presenting the basic program to the client, the architect makes a new program plan based on input from the client, repeats, and revises it until an agreement is reached. See on Figure 1:

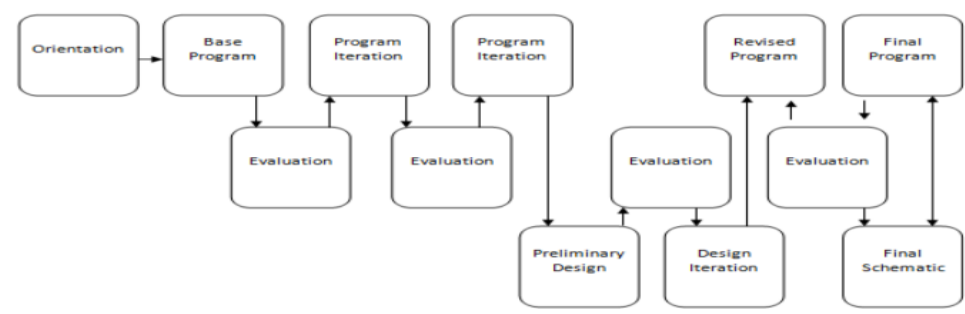

Fig. 1. Kurtz programming (Baskoro 2015). 
The process carried out is to develop a schematic design which is carried out after the last iteration of programming. There will be continuous revisions until an agreement is reached. Programming the Kurtz model has four main stages. The role of the client in this model is as a user or owner and the client is involved in every programming. The Kurtz model of programming emphasizes the design process during programming. It aims to provide direct input into the program proposed to the client. See on Figure 2:

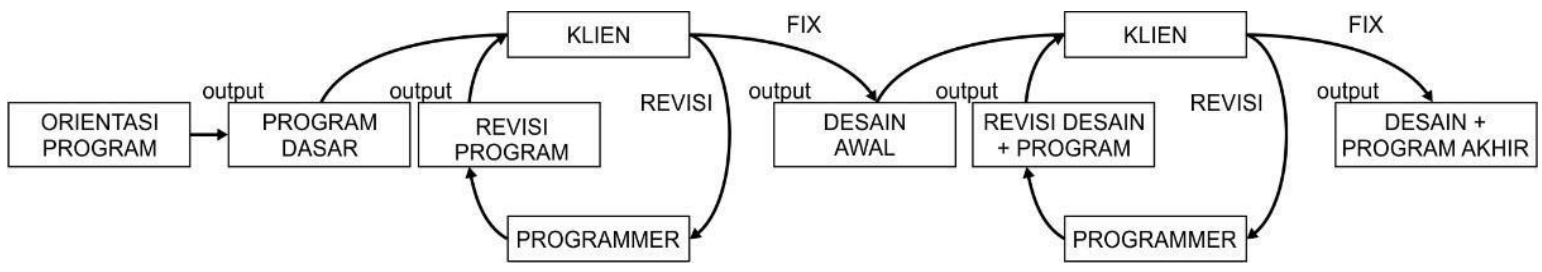

Fig. 2. Schematic of the Kurtz Method (Baskoro 2015).

Programming is done through surveys, interviews, questionnaire development, observation, documentation. The data that has been obtained is then analyzed to formulate a schematic concept consisting of zoning, grouping, room size, room orientation, circulation flow, a pattern of relationships between spaces. Ideas After the schematic design is made, the next step is to explore ideas visually. Methods covering the phasing or design process are as follows: (a) Transformation of design ideas through sketch images (Olofsson and Sjolen 2006), (b) alternative ideas and design sketches; (c) election of design alternatives; (d) creating working drawings includes view drawings, detail drawings, and perspective drawings; (e) presentation media using three-dimensional images and animations.

\section{Results and Discussion.}

Interior design is based on several stages. This activity aims to be able to formulate design problems in the field properly and appropriately. To be able to formulate and solve design problems, several approaches are applied and it is not uncommon to use more than one approach. This is so that the design results obtained are maximal and follow user needs. The GNI building in Gresik has a function as a performance building and also as a cultural heritage building with the aim that later visitors can enjoy the space facilities to the maximum before and after enjoying the shows that have been displayed. Not only visitors but also the comfort of the talents and building managers are also considered to feel safe and comfortable when inside the building. To facilitate this, a room like the following is needed:

- Lobby

The lobby at GNI Gresik is located in the earliest room found in the entire building. The lobby itself functions as a space that connects the entrance of the building (cinema, hotel, apartment, etc.) with the rooms inside. The lobby can also be an open transition room and also a place to wait and pass, and to get information.

- Auditorium

The auditorium at GNI Gresik is an area devoted to the audience so that they can enjoy the performances that are presented comfortably without disturbing other rooms. The auditorium itself is generally a large room that is usually used for public meetings, performances, and so on.

- Satge

The stage at GNI Gresik is a high-floor area that is used specifically for performing performers and as a boundary between the audience and performers. Usually, there are properties as a tool or support for a show.

- Make-Up Room

The make-up room at GNI Gresik is a space for talents to perform activities to beautify or improve themselves, as well as changing appearances for the needs of the shows that will be played.

- Backstage

The backstage at GNI Gresik is a space used for the waiting area or preparation of performers before going on stage. 
- Control Room

The Control Room at GNI Gresik is a room that functions to regulate lighting and sound systems for maximum comfort when the show is taking place in the auditorium and stage.

- Office

The office at GNI Gresik is a place where administrative activities or activities are carried out, namely in the form of a work unit consisting of a room, equipment, and workers.

- Canteen

The canteen at GNI Gresik is a place to buy food and soft drinks, either for lunch waiting when entering the auditorium, for lunch while in the auditorium, or for food for building managers.

Ergonomics is the study of the alignment of humans or workers with their work environment or vice versa to increase productivity and efficiency as high as possible with a safe and comfortable situation or atmosphere. The goal of ergonomics is for the workforce to achieve high (productive) work performance but in a safe and comfortable atmosphere. Interior design must be able to create facilities for the benefit of humans, so several elements must be considered, namely; activity, capacity, and anthropometry. To fulfill the function of the space to be able to facilitate users in doing activities in it, several disciplines are needed, these disciplines are the Ergonomics approach. The discipline of ergonomics provides solutions to the psychology and behavior of design users in their activities, both in terms of comfort and safety. Related to human behavior and psychology, it is intended for selecting furniture and adjusting themes to user activities (Sumarno, Sunarmi, and Kusmadi 2021).

Various considerations needed in a design of course must have a basis or basis in the size of the interior elements so that they can be accessed by humans properly and correctly. In the use of furniture, things that need to be considered related to comfort, security, and safety are: The size of the furniture is according to the size of the human body (Wang, Shi, and Niu 2021), (Kahya 2019), (Sumarno and Indarto 2016). The function of the furniture is according to the function of the room (Esen and Uysal 2019). The selection of structures and materials must meet the criteria relating to the structure of the builder and the quality of the materials. Structure relates to the construction obtained from the activities that occur, and the use of appropriate materials. In the GNI Interior Adaptation Revitalization Planning in Gresik, the standardization of furniture design was taken from the book (Panero and Zelnik 1996; Joseph De Chiara, Panero, and Zelnik 1992). The standards used include the following. On figure 3, figure 4, figure 5 , figure 6 .

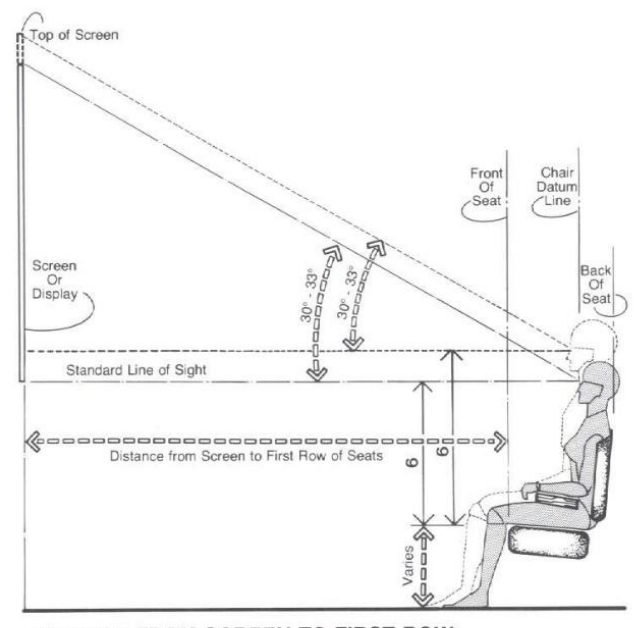

DISTANCE FROM SCREEN TO FIRST ROW

\begin{tabular}{|ccc|}
\hline & in & cm \\
\hline $\mathbf{A}$ & 59.0 & 149.9 \\
\hline $\mathbf{B}$ & 56.3 & 143.0 \\
\hline $\mathbf{C}$ & 57.8 & 146.8 \\
\hline $\mathbf{D}$ & 68.6 & 174.2 \\
\hline $\mathbf{E}$ & 72.8 & 184.9 \\
\hline $\mathbf{F}$ & 28.1 & 71.4 \\
\hline $\mathbf{G}$ & 29.6 & 75.2 \\
\hline $\mathbf{H}$ & 27.3 & 69.3 \\
\hline $\mathbf{J}$ & 9.3 & 23.6 \\
\hline $\mathbf{K}$ & 33.9 & 86.1 \\
\hline & 36.6 & 93.0 \\
\hline
\end{tabular}

Fig. 3. Standard Distance Between Audience and Source Screen or Stage (Joseph De Chiara, Panero, and Zelnik 1992). 

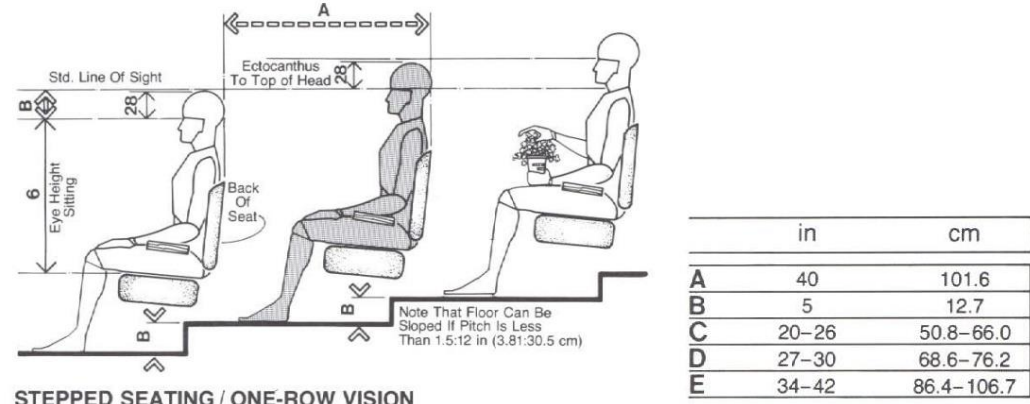

Fig. 4. Standard Front Seat Distance from Rear View Source (Joseph De Chiara, Panero, and Zelnik 1992).

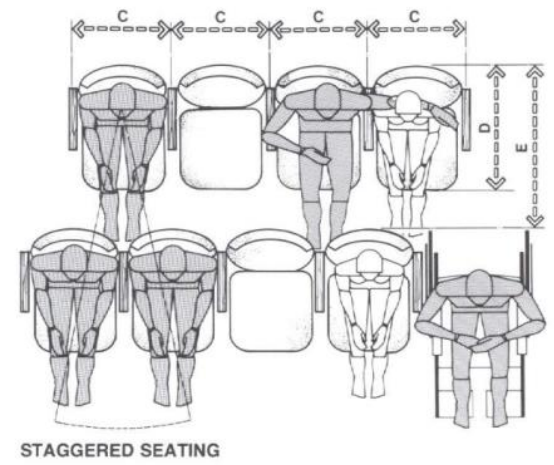

\begin{tabular}{|ccc|}
\hline & in & cm \\
\hline $\mathbf{A}$ & 59.0 & 149.9 \\
\hline $\mathbf{B}$ & 56.3 & 143.0 \\
\hline $\mathbf{C}$ & 57.8 & 146.8 \\
\hline $\mathbf{D}$ & 68.6 & 174.2 \\
\hline $\mathbf{E}$ & 72.8 & 184.9 \\
\hline $\mathbf{F}$ & 28.1 & 71.4 \\
\hline $\mathbf{G}$ & 29.6 & 75.2 \\
\hline $\mathbf{H}$ & 27.3 & 69.3 \\
\hline $\mathbf{I}$ & 9.3 & 23.6 \\
\hline $\mathbf{J}$ & 33.9 & 86.1 \\
\hline $\mathbf{K}$ & 36.6 & 93.0 \\
\hline
\end{tabular}

Fig. 5. Standard Distance Between Adjacent Seat Source (Human Dimensions and Interior Space by Julius Panero and Martin Zelink. 1979, p. 295).

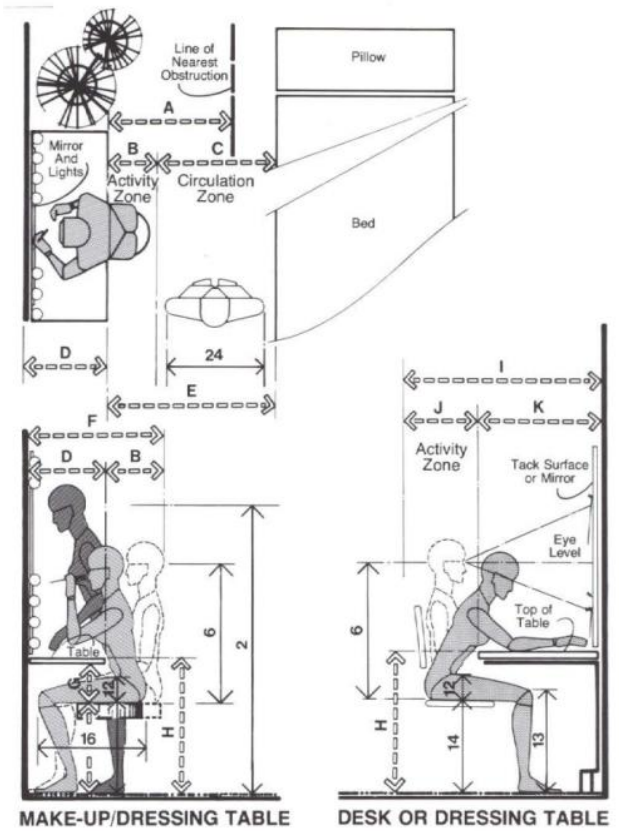

\begin{tabular}{ccc|}
\hline & in & $\mathrm{cm}$ \\
\hline$\overline{\mathbf{A}}$ & $24-28$ & $61.0-71.1$ \\
\hline $\mathbf{B}$ & $12-16$ & $30.5-40.6$ \\
\hline $\mathbf{C}$ & 30 & 76.2 \\
\hline $\mathbf{D}$ & $16-24$ & $40.6-61.0$ \\
\hline $\mathbf{E}$ & $42-46$ & $106.7-116.8$ \\
\hline $\mathbf{F}$ & $28-40$ & $71.1-101.6$ \\
\hline $\mathbf{G}$ & $7 \mathrm{~min}$. & $17.8 \mathrm{~min}$. \\
\hline $\mathbf{H}$ & $28-30$ & $71.1-76.2$ \\
\hline $\mathbf{J}$ & $42-54$ & $106.7-137.2$ \\
\hline $\mathbf{J}$ & $18-24$ & $45.7-61.0$ \\
\hline $\mathbf{L}$ & $24-30$ & $61.0-76.2$ \\
\hline $\mathbf{M}$ & $62-72$ & $157.5-182.9$ \\
\hline $\mathbf{N}$ & $20-24$ & $50.8-61.0$ \\
\hline $\mathbf{D}$ & $16-20$ & $106.7-121.9$ \\
\hline $\mathbf{P}$ & 18 & $40.6-50.8$ \\
\hline $\mathbf{Q}$ & 42 & 45.7 \\
\hline & & 106.7 \\
\hline
\end{tabular}

Fig. 6. Standard Sizes of Source Dressing Room Requirements (Human Dimensions and Interior Space by Julius Panero and Martin Zelink. 1979, p. 153

Aesthetics is a science that studies everything related to beauty, studying all aspects of what we call beauty. In the field of interior, beauty is one thing whose role is very important. Beauty can influence the interest of many people to determine whether to visit the object or not. In addition, beauty can also affect the psychology of people who see or feel it and can cause different feelings for each individual. The interior must contain aesthetic elements that refer to design principles such as proportion, space scale, balance, space harmony, space unity, and variety, space rhythm, space emphasis, and beautiful 
things such as space accessories. In the adaptation of GNI in Gresik, the aesthetic approach is derived from the following styles and themes. The theme used in the GNI adaptation in Gresik is "Damar Kurung". Damar Kurung is a paper lantern craft with a framework made of cut bamboo blades facing each other to form a square with oil paper attached on all four sides, the blanks of which are painted with various funny pictures that tell of major activities around the community. Gresik, such as the milkfish market festival, takbiran activities to welcome Eid al-Fitr, etc. In its linguistic sense, 'damar' means a lamp or candle, and 'kurung' means a lid, so Damar Kurung means, a lamp that is closed or locked up. According to the word Damar Kurung has the meaning of mendamari which means to illuminate.

The shift in the function of Damar Kurung which was originally in the form of a lantern with the division of images on each side consisting of two parts and more simply developed into a twodimensional painting by dividing three to four parts in one painting using a dividing partition. The division of partitions in Masmundari's painting is Masmundari's representation of several events he saw, for example: in the painting Cycling, Masmundari divides the painting into three parts, Masmundari sees cycling activities carried out by several women, but in another scene, Masmundari sees several events such as the activities of some people who are exercising and found the activities of people who are feeding their children. Masmundari describes the division of several scenes into several parts using vertical lines in his paintings. Damar Kurung itself has a deep meaning, which is related to education, especially for small children, which is manifested through images such as reciting activities, tarawih, and tadarusan. Damar Kurung is placed in a house where a house is a place for people to go home and go with the hope of always seeing the pictures contained in the Damar Kurung with the hope of a better pattern of life and always remembering the Creator.

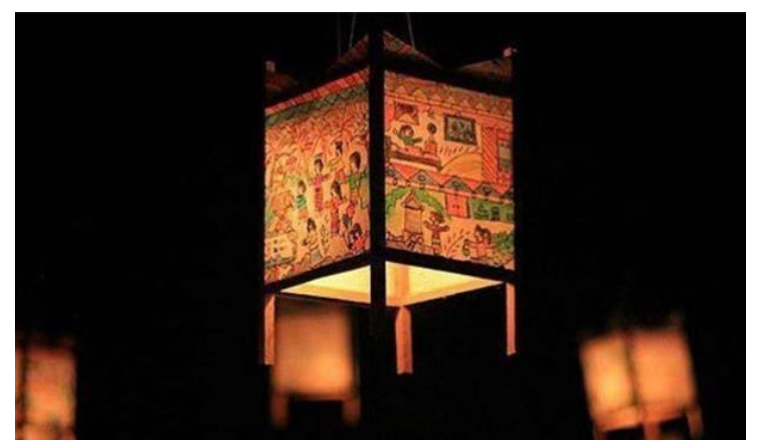

Fig. 7. Damar Kurung Gresik.

Art Deco (Decorative Art) or decorative art is a style that emerged in the 1920s whose presence was influenced by social unrest in society that demanded reforms to meet the needs of that era. The turmoil in society led to the emergence of new ideas. The industrial revolution was also one of the factors driving the emergence of Art Deco. Art Deco style is a style of art that is characterized by luxury and freedom. Art deco appears simpler and more geometric without losing the classic impression. This was adjusted to the demands of industrialization at that time. Art deco artworks are more geometrically symmetrical than asymmetrical, with the main goal of ending the conflict between art and industry. The art deco building is easily recognizable from the spirit of its decoration, which emphasizes the beauty of the building by using smooth curved lines, in addition to playing with firm horizontal geometric lines. The colors that are often used are pastel colors or tropical natural colors such as yellow, navy blue, leaf green, pink, sand color, or other matching colors.

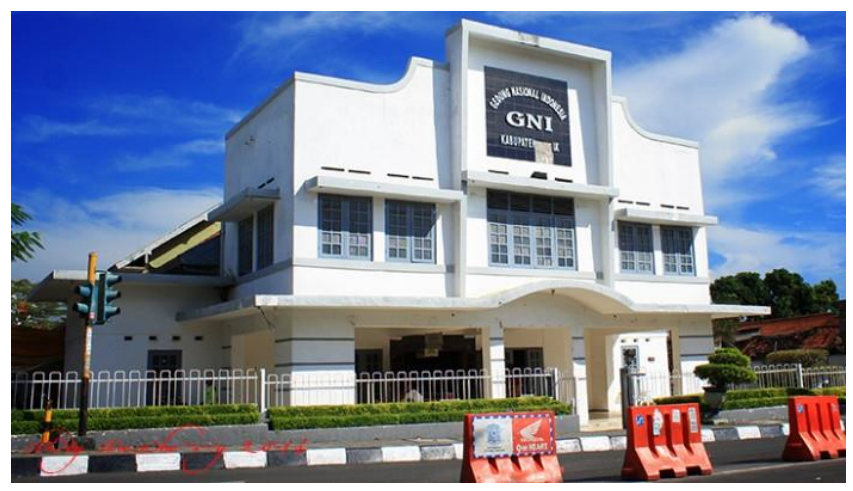

Fig. 8. GNI Gresik façade. 
The technical approach to adapting to GNI in Gresik is the acoustics in the auditorium. Because the interior of the auditorium requires several acoustic technical approaches such as the selection of materials and materials, several things must be reviewed before designing the interior of the ballroom itself. Sound-absorbing materials used in acoustic design that is used as sound controllers in noisy rooms and can be mounted on the walls of the room or hung as space absorbers are in the form of porous materials and absorber panels and carpets. Sound absorbing materials and constructions used in the acoustic design of an auditorium or used as sound control in noisy rooms can be classified into porous materials, panel absorbing materials, carpets. The location of the design is geographically from the location of the residential area, the Radar Gresik Office from the north side. The south boundary is Jl. Jaksa Agung Suprapto, Bank Jatim Syariah Cab. Gresik. The east side is bordered by Jl. Pahlawan and the west side is a residential area. See on Figure 9.

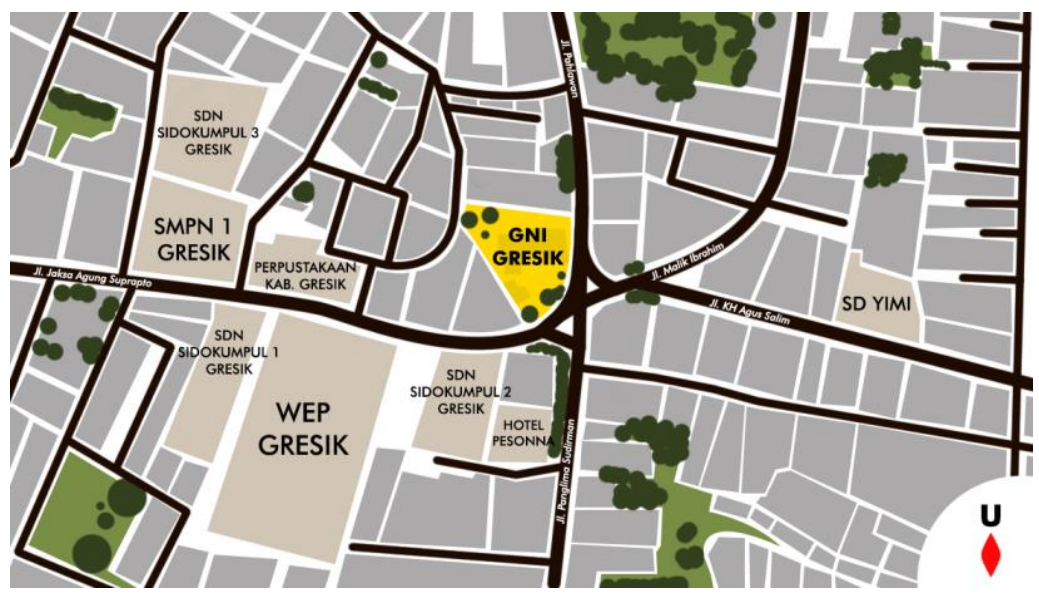

Fig. 9. Siteplan GNI Gresik.

Based on the area boundary where the Gresik GNI is located, it can be seen that the GNI location is at a highway intersection. The shape and style of the building are very striking among its surroundings, making the existence of GNI Gresik very well known to road users because it is an interesting object to look at, plus there are traffic lights on the highway, so that road users who are waiting for traffic lights can see clearly. the building is clear. The relationship between spaces is the location or position of the spaces in a building, wherein the placement, whether it should be far apart, close together, or maybe even combined. Determination of the relationship between spaces is based on the similarity of activities, activities that need to be supported by other activities where these activities require separate spaces. In planning for Interior Revitalization at the Indonesian National Building in Gresik using an Art Deco Adaptation with the Damar Kurung Theme, the relationships between spaces that occur are as follows, see in Figure 10.

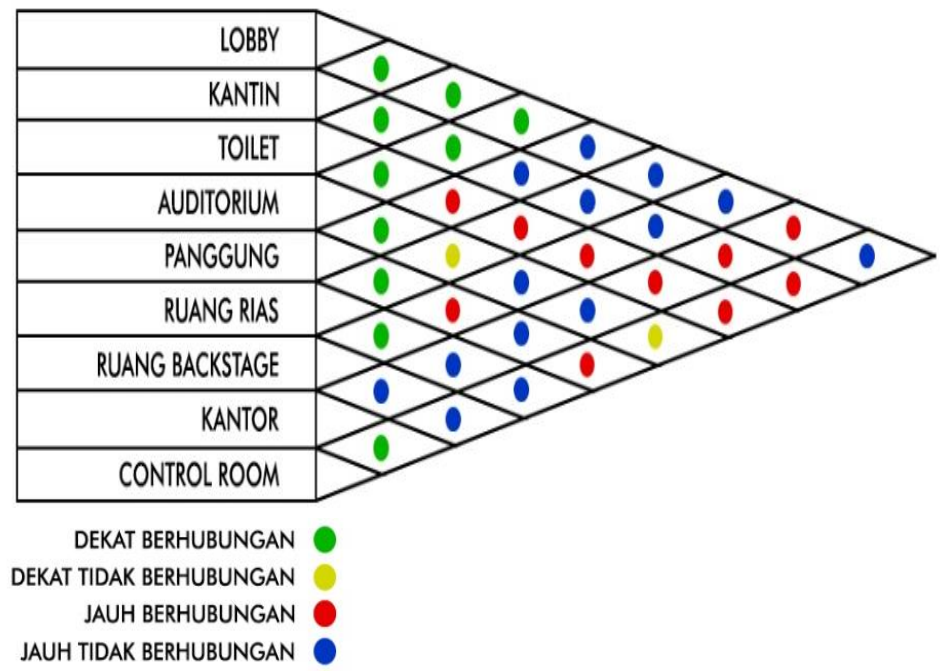

Fig. 10. Relations between GNI Gresik's Spaces. 
Grouping and zooning in interior planning as an effort to group space based on space user analysis is very necessary so that space users who are carrying out activities in the room can carry out their activities optimally and without any interference from other people (Mittal 2021), (Cho and Suh 2020). It is called grouping zoning. Based on its nature, group zoning is divided into several parts, namely. Can see on Table 1.

Table 1: Room classification.

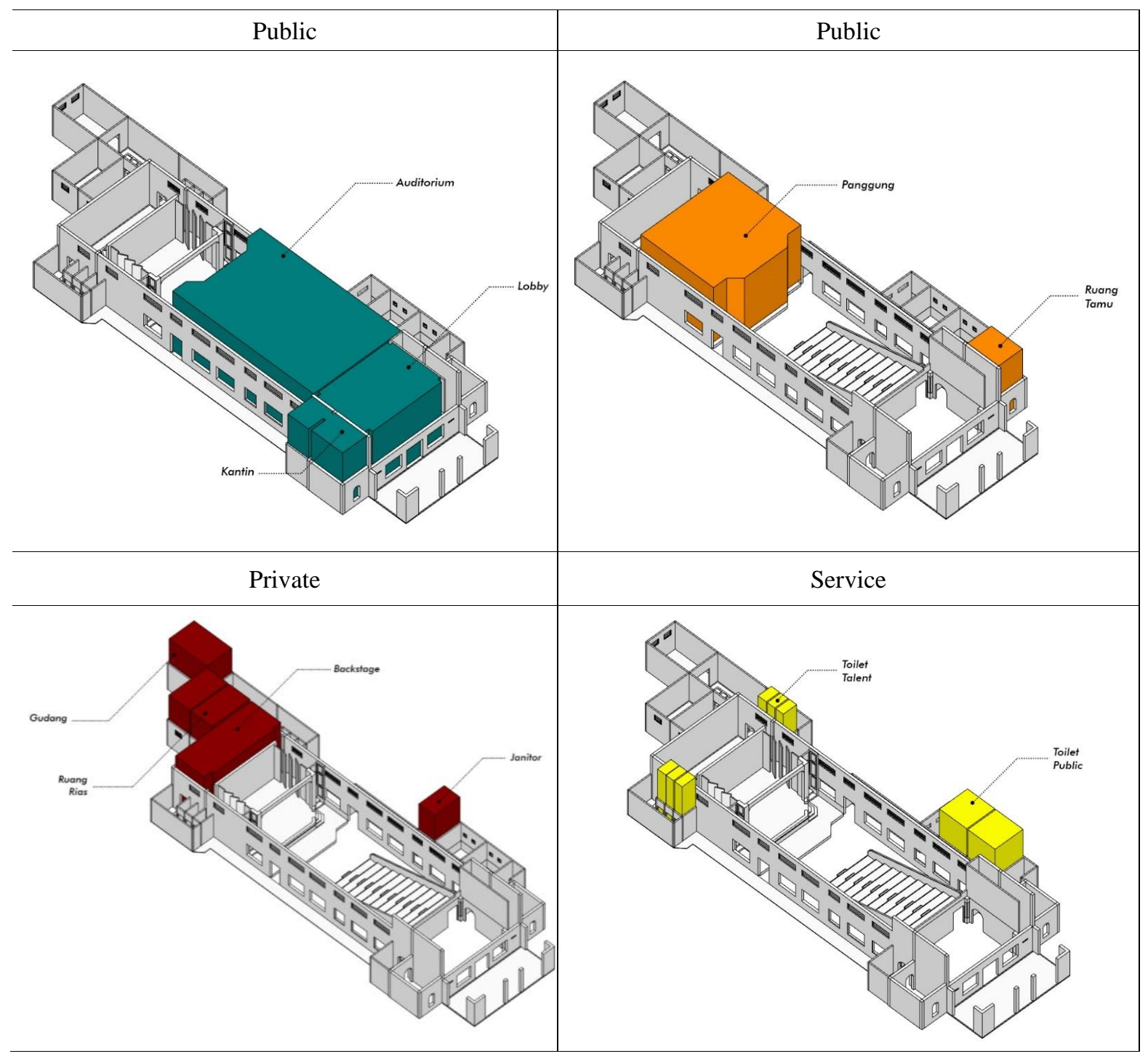

Laying the layout must consider the active area and passive area. The active area is an area used by space users to move around or be used for moving activities, so as much as possible to avoid placing furniture in the area. While the passive area is an area that is not used by space users to move around or for moving activities, so that the placement of the furniture in the area will support the activities of space users. The following is the design of the furniture layout in the GNI Gresik plan: 

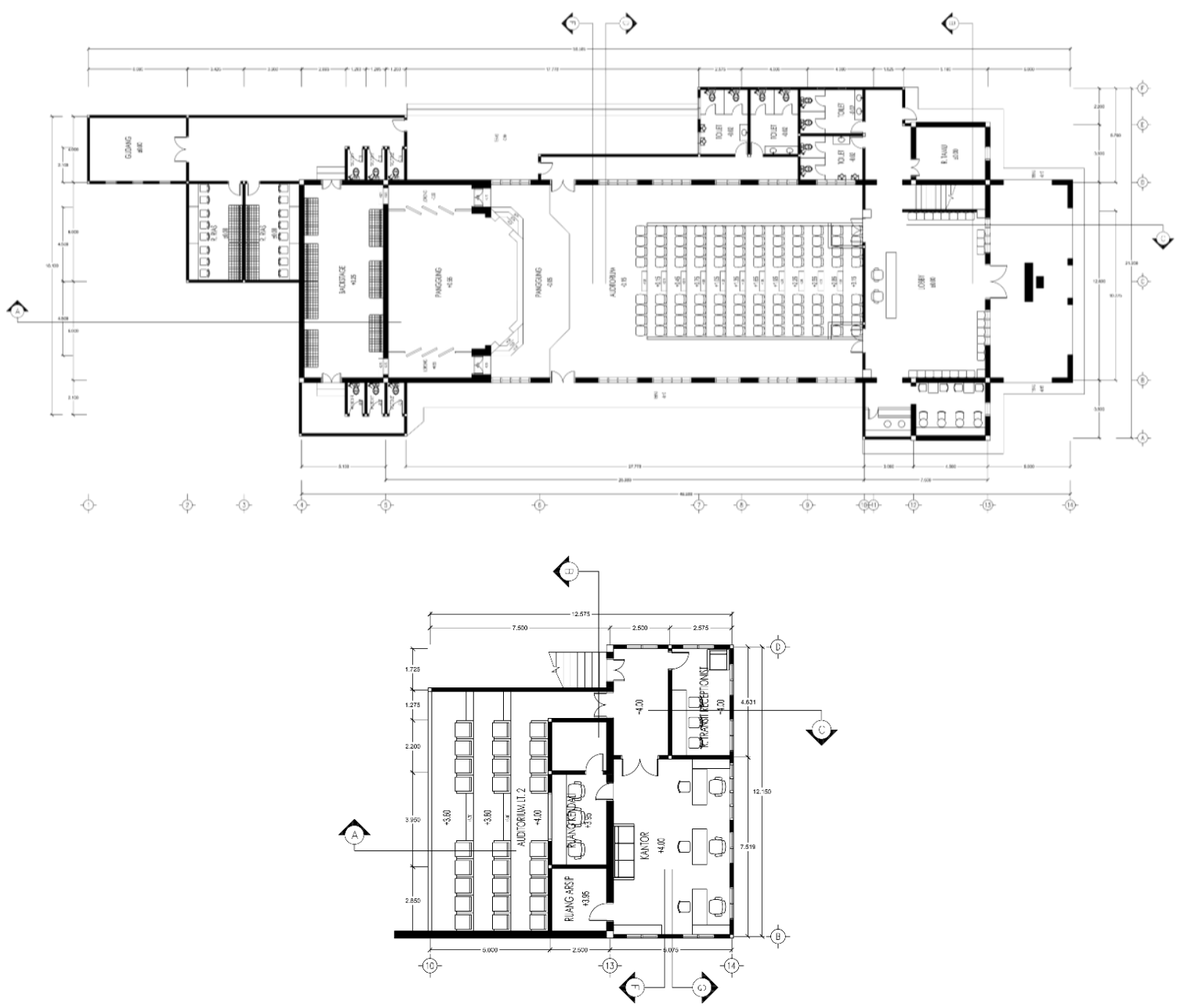

Fig. 11. Floor Plan Layout

Perspective as in interior design as an effort to visualize design objects with 3Ds Max so that design images become more simulative, scalable, aesthetic and even atmosphere, the spirit of space is also able to be presented.

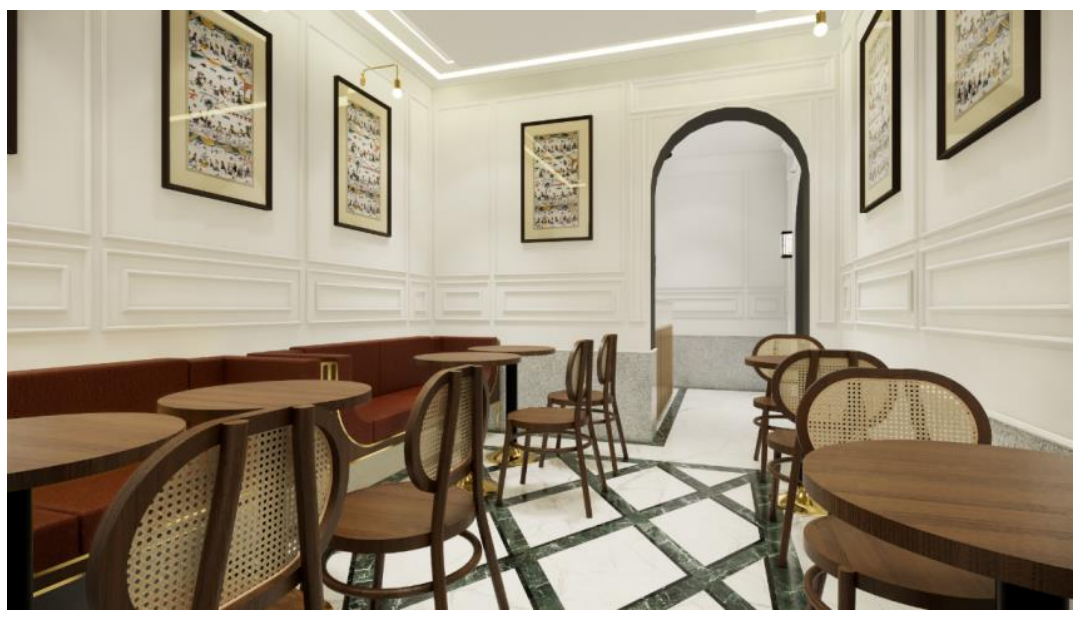

Fig. 12. Canteen. 


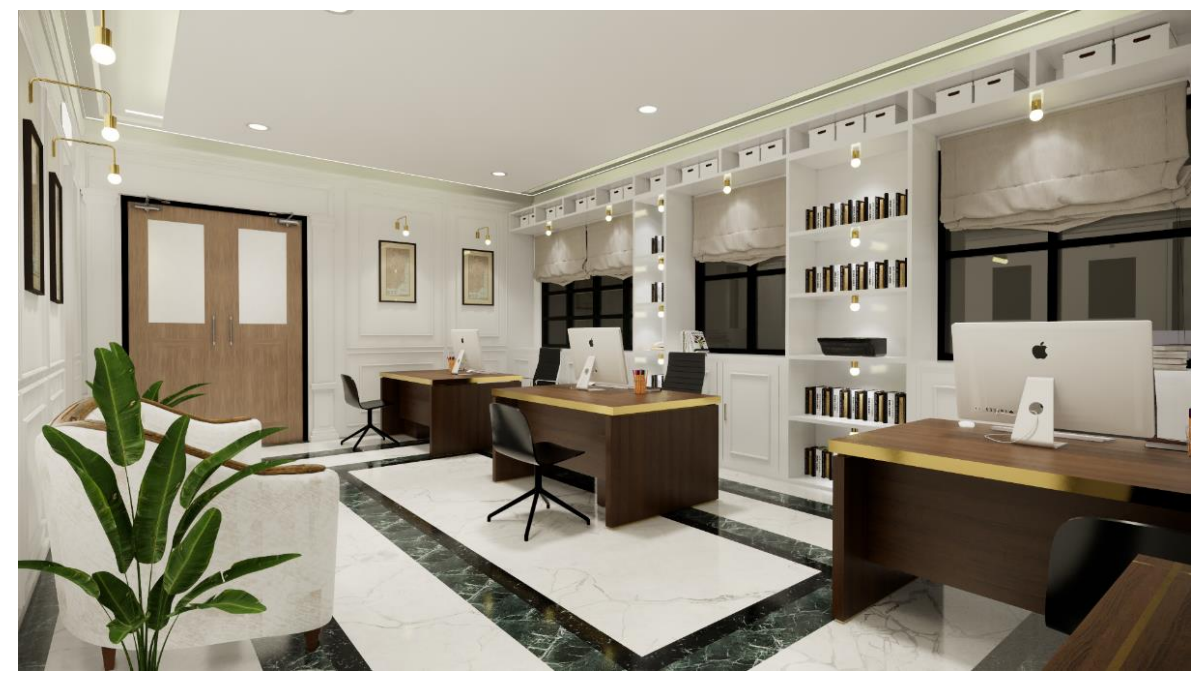

Fig. 13. Office.

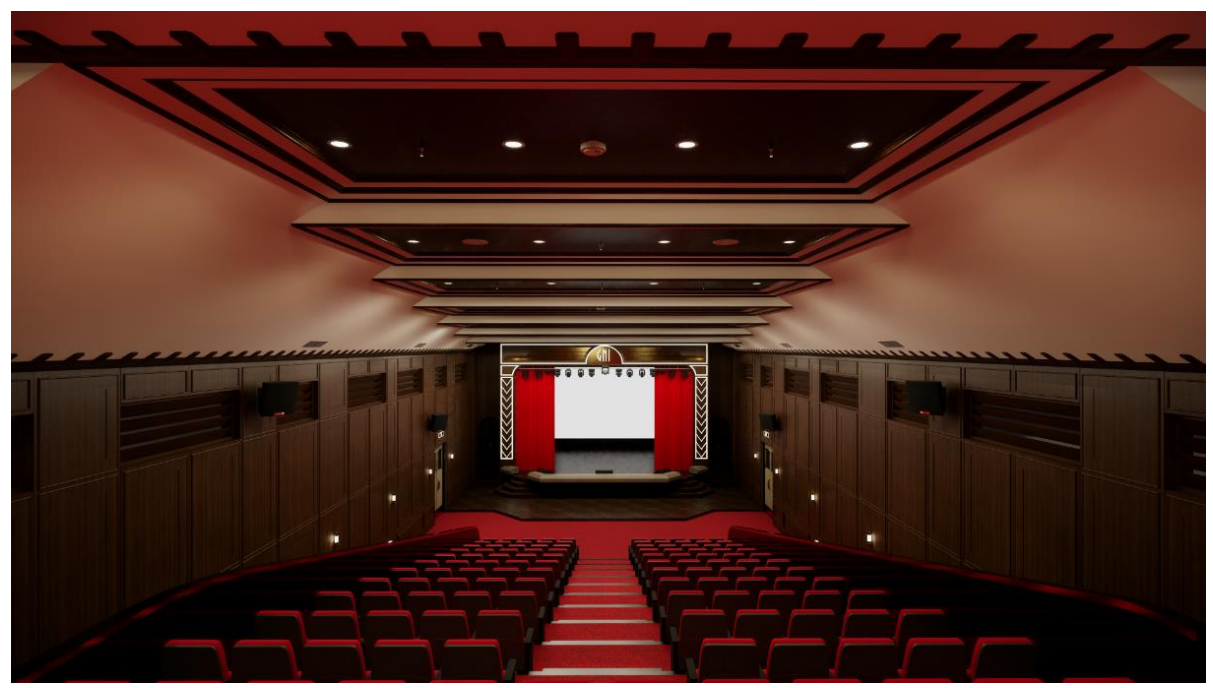

Fig. 14. Auditorium.

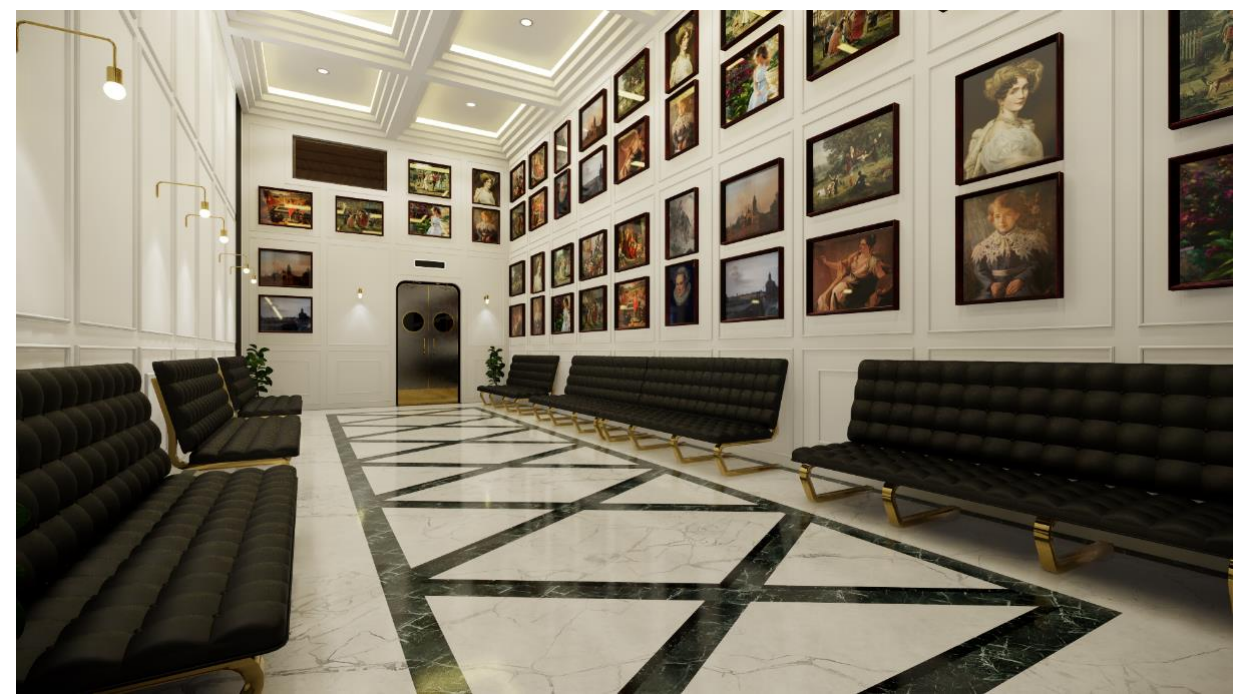

Fig. 15. Backstage. 


\section{Conclusion}

Interior Revitalization Planning at the Indonesian National Building in Gresik by Adapting Art Deco Style with the Damar Kurung Theme in Gresik is planning to restore the function of the building from a cultural heritage building which is a performance building that functions as a means or forum for the gathering of artists, especially from Gresik. This plan is expected to provide the necessary facilities for artists, especially from Gresik and is also expected to be used to preserve the arts in Gresik so that they are not lost to the times so that the GNI Gresik building can provide benefits to the surrounding community.

\section{References}

Baskoro, Satyo. 2015. "Metode Pemrograman John M. Kurtz." Prezy. 2015. https://prezi.com/iOuaulk42k-u/metodepemrograman-john-m-kurtz/\#: :text=Skema Pemrograman Kurtz\&text=Merupakan tahap pengkajian filosofi\%2C,klien berdasarkan konsultasi dengan klien.\&text=Proses ini menyajikan desain awal,terus menerus hingga tercapainya.

Cho, Ji Young, and Joori Suh. 2020. "Interior Design." In Encyclopedia of Creativity, 685-94. Elsevier. https://doi.org/10.1016/B978-0-12-809324-5.23600-6.

Christianna, Aniendya. 2018. "The Representation Of Javanese Women In Damar Kurung Painting - Gresik." Mudra Jurnal Seni Budaya 33 (3): 295. https://doi.org/10.31091/mudra.v33i3.376.

Esen, Rasit, and Burhanettin Uysal. 2019. "The Analysis of Living Room Furniture and Room Spaces Used by Families Relation of West Black Sea Region in Turkey." Engineering Science and Technology, an International Journal 22 (2): 692-96. https://doi.org/10.1016/j.jestch.2018.12.011.

Joseph De Chiara, Julius Panero, and Martin Zelnik. 1992. Time Saver Standards for Interior Design and Space Planning. New York: Mc Graw Hill.

Kahya, Emin. 2019. "Mismatch between Classroom Furniture and Anthropometric Measures of University Students." International Journal of Industrial Ergonomics 74 (November): 102864. https://doi.org/10.1016/j.ergon.2019.102864.

Mittal, Nikita. 2021. The Key of Interior Design (Illustration of Methods and Principles). Standard Book House Since 1960.

Olofsson, Erik, and Klara Sjolen. 2006. Design Sketching.Pdf. 2nd ed. Klippan, Sweden: KEEOS Design Book.

Panero, Julius, and Martin Zelnik. 1996. Human Dimensión \& Interior Space. A Source Book of Design Reference Standards Publicado Por Watson-Guptill Publications, New York. Ediciones G. Gili, S.A. de C.V. México,.

Prompayuk, Supoj, and Panayu Chairattananon. 2016. "Preservation of Cultural Heritage Community: Cases of Thailand and Developed Countries." Procedia - Social and Behavioral Sciences 234 (October): 239-43. https://doi.org/10.1016/j.sbspro.2016.10.239.

Sahertian, Pieter, and Umiati Jawas. 2021. "Culture and Excellent Leaders: Case of Indigenous and Non-Indigenous Indonesian Leaders." Heliyon 7 (11): e08288. https://doi.org/10.1016/j.heliyon.2021.e08288.

Shahi, Sheida, Mansour Esnaashary Esfahani, Chris Bachmann, and Carl Haas. 2020. "A Definition Framework for Building Adaptation Projects." Sustainable Cities and Society 63 (December): 102345. https://doi.org/10.1016/j.scs.2020.102345.

Sumarno, and Indarto. 2016. "Implementasi Prinsip Quadrow Helix Dalam Rancang Bangun Show Room Di Sentra Industri Kerajinan Rotan Sukoharjo." Surakarta.

Sumarno, Sunarmi, and Kusmadi. 2021. "Old Javanese Seating Equipment as Depicted on the Base Relief of Borobudur Temple." Journal of Southwest Jiaotong University 56 (4).

Wahyu, Rizky Sandika. 2013. "Damar Kurung (Makna Lukisan Damar Kurung Sebagai Kesenian Masyarakat Gresik).” AntroUnairDotNet.

Wang, Xiaoxiao, Ruiting Shi, and Fangru Niu. 2021. "Optimization of Furniture Configuration for Residential Living Room Spaces in Quality Elderly Care Communities in Macao." Frontiers of Architectural Research, December. https://doi.org/10.1016/j.foar.2021.11.002. 